\title{
Objects as identity markers - Ways of mediating the past in a South Sámi and Norse borderland
}

\author{
Grete Swensen*
}

\begin{abstract}
Museums have several means of communicating with their audiences. The problems discussed here concern how local museums interact with their audience when the past they want to portray is multiple, complex and sometimes disputed. It is based on an analysis of three exhibitions in local museums situated in a region where archaeological findings indicate that the South Sámi have been present since the Late Neolithic and the Bronze Age. It highlights the various ways in which the pluralistic past in the region is being portrayed by asking whether its history appears as neutralized, i.e. transmitted in passive impartial terms, or is exoticized, repressed or mediated through other images. The one common identity marker the three exhibitions share, although portrayed in different ways and with different effects, is the gåetie, a turf hut in common use in the South Sámi region. A tendency to neutralize the multiple and complex past in the South Sámi region takes place, either by operating in a form of 'timeless past' or by referring to a shared 'far away past' as fishers and hunters. By barely mentioning cultural encounters, the South Sámi and the Norse are primarily presented as ethnic groups who have lived isolated and independent of each other.
\end{abstract}

Key words: disputed heritage; identity markers; South Sámi; perceptions of the past; museum exhibitions

\section{Introduction}

The main aim of this article is to discuss what means of communication local museums use when the past in question is multiple, complex and sometimes disputed. The study is based on an analysis of three exhibitions in museums situated in a locality where reindeer herding still provides the main income for the South Sámi families involved in the trade. The context is social encounters which have taken place between the South Sámi and the Norse people for centuries. ${ }^{1}$ Two of the museums in question are situated in the north-eastern part of Hedmark County, Norway, in the municipality of Engerdal, where research has shown that the region contains cultural heritage indicating Sámi and Norse coexistence probably as far back as the Late Neolithic and the Bronze Age (Amundsen 2003, 2011). The third museum is Härjedalens fjällmuseum. It is situated in Funäsdalen, Sweden, and the museum presents itself as a museum 'for everyone' that tells the history of 'mountain farmers, Sámi and labourers in the iron works. ${ }^{2}$

Current discourse among scholars and museum professionals mirrors a general tendency within heritage research to put more emphasis on situations of conflict, and hidden, dark or difficult history (for further discussions see for instance Connerton 1989; Langfield et al. 2010; Logan and Reeves 2009; Tunbridge and Ashworth 1996). This turn is reflected in the policies of several larger museums and in their choices concerning how to mediate history and culture in their exhibitions. Many museums of cultural history in Norway were established in accordance with the ideas of the nation state and still bear some traces from this period, that is, the late nineteenth century and the early twentieth century. They were part of the large narratives affiliated with the national romantic period. There is wider understanding among museum professionals today that their institutions, through choices of sources and focus, have managed 


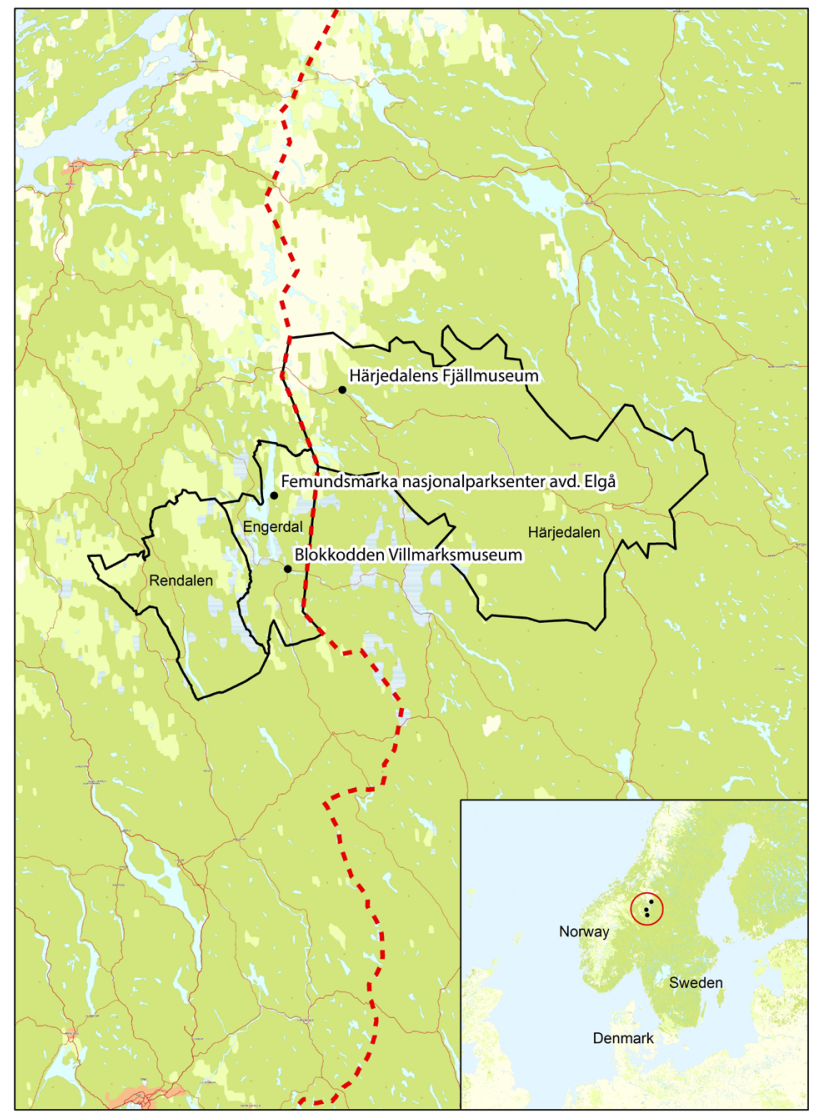

ni<U
EUREF99八TM32

(2)

Figure 1. Map showing where the three examined museums are located. Copyright: The Norwegian Mapping Authority ways of ways of mediating museum narratives, but this also intensifies the need to rewrite the grand historiographical narrative. The presentation of the methods used in the study functions as an introduction to the result section, which is a description of the three examined museum exhibitions. The discussion begins by comparing the findings to other studies of Sámi exhibitions. It points to a tendency that takes place, to repeat certain common traits regardless of where the institutions are situated (in the capital, the South or the North Sámi region). All three museum institutions in question have involved local experts in their museum work. The overall tendencies of the study are discussed in light of the potential of actively involving various user groups (source communities) to mediate a complex and partly disputed history with the intent of avoiding simplification or suppression. 


\section{Research framework}

Although museums still to a large extent are identified with the collections of objects they hold, new ideas about a museum's prime functions will influence how objects are selected, displayed and used as identity markers. Some things happen with objects when they are included in the museum collection, conserved and selected for exhibiting. They pass into a new context, and are ascribed a new symbolic meaning. When it turns into heritage it becomes defined as 'a mode of cultural production that has recourse to the past and produces something new. Heritage as a mode of cultural production adds value to the outmoded by making it into an exhibition of itself' (Kirschenblatt-Gimblett 2012: 199). Similar processes are described by Sharon Macdonald as 'heritage turning the past into The Past' (Macdonald 2013: 18). As society changes even more rapidly due to new technology and global interaction, there might be reason to expect the importance of this cultural and symbolic production of meaning to increase.

Museums, libraries, and cultural institutions provide opportunities for people to understand who they are, were, and might be. The way they engage the public by providing new insight and instilling inquisitiveness has been described by Smith (2014) as 'the museum effect'. Traditionally, museums were identified as institutions with prime aims to ensure transfer of historic knowledge, i.e. their educational role. In addition they have been closely coupled to the role as object collector. These ideas are still vivid among some museum visitors. Among the museum profession, however, new ideas about the museum's societal role have renewed their way of thinking both about what prime aims of a museum should be and about relevant ways of mediating their messages. ${ }^{3}$ Rapid societal changes in recent decades have influenced how museum curators and researchers understand and define the main objectives of the museum as a mediator. The role of museums has been referred to as 'contact zone' (Clifford 1997) and 'civic laboratories' (Bennett 2008), and their intentions are discussed in the light of concepts such as 'the new museology' (Vergo 1997) and the 'post-museum' (Hooper-Greenhill 2007) (see Barrett 2011: 110-114 for a detailed description of this turn in perspectives). As Smith (2015) has pointed out, the calls for museums to engage themselves in community activities has changed how they view their educational role. It is today more a question of learning and lifelong learning - referred to in the museum discourse as the three L's (Smith 2015:461).

To a large extent such new roles and broadened intentions are based on paramount objectives. It can be discussed to what extent they can be transferred into practice in local museums with different impact areas. Despite the recent major reorganization of the museum structure in Norway (referred to in policy documents as a consolidation process) (St.meld. no. 22, 1999-2000), a series of regional and local museums still depend heavily on their community for responses - not necessarily in economic terms, but in terms of a need for support and legitimation.

Community involvement in various forms is considered a cornerstone in much local museum work. The need to shift patterns of power and authority becomes apparent when museums collaborate with their local communities (Swan and Jordan 2015: 40). Community has in recent years become a term that has taken up a life of its own. As part of the general societal and political discourse, it has 'become near-mandatory, operating as it does as a salient and enduring feature of our everyday lives'. It has 'too easy become ... a solution rather than something to be explained' (Waterton and Smith 2010: 4-5), which underlines the importance of defining intentions, target groups and long-term effects of community involvement. In the context of this paper community is not used in terms of defining a uniform entity. It is more convenient to see the community as a museum's practice field. When Barrett relates community to the public sphere, she stresses that 'an important possibility with community is that it does not always seek representation in the public sphere [...]. Alternative publics cannot, and do not, necessarily enter the "democracy" of the dominant public sphere' (Barrett 2011: 135), because other major factors are also in force - or as Thomas (2010) points out, 'The function of the museum as a communicator cannot be separated from cultural issues of knowledge, power, identity and language' (Thomas 2010: 9). Decolonization has led to discussions about dissonant or disputed history and heritage, where museum professionals have also taken part (Onciul 2014). Community involvement has been practised with considerable success in museums that have prioritized paying special attention to parts of their collections which stem 
from indigenous peoples. The term 'source community' refers to the communities from which museum collections originate. Such changes in museums' approaches and methods have influenced the relationship between the museum professionals and the local communities. Today the relationship has a character of being much more of a "two-way process, with information about historic objects now being returned to source communities, and with community members working with museums to record their perspectives on the continuing meanings of those objects' (Peers et al. 2003: 1). Although the term has often been used primarily to refer to indigenous peoples, it has a much wider field of action. It can be applied to every group museums have collected from; local people, diaspora and immigrant communities, religious groups, settlers and indigenous groups (Peers et al. 2003: 2). The relationship which has developed between the museums and local communities has proven to be beneficial in a series of ways. New insight has been provided both concerning objects in the collections and the meaning the objects have in contemporary culture, but not least about new methods in museum work and the interpretation of the museum's role in a wider societal context. The relationship described between museums and source communities can be viewed as a sign that the museum professionals are now better prepared for 'tackling messy problems' because 'new roles [are] required ... in facilitating political disagreement and debate' (Lynch 2014: 95).

According to Richard Sandell (Sandell 2007; Sandell and Nightingale 2013) a growing number of institutions are concerned to construct new narratives that represent a plurality of lived experiences, histories and identities. 'The challenge of the post-colonial approach to contemporary society is to question the historiographical narrative as told within the parameters of a univocal point of view' (Angelis et al. 2014: 2). One of his main concerns relates to the fact that there is still a limited understanding of the social and political effects of these strategies (Sandell 2007). Museum professionals are experiencing that societal changes are 'challenging history in the museum' (Kidd et al. 2014). Not enough attention has been paid to immigrant communities as visitors, consumers, or even producers of museum experiences. They establish a possible framework for better understanding what it means to engage with these communities in a meaningful way (Stein et al. 2008: 180).

An important milestone concerning these topics was reached in 2005 by the Framework Convention on the Value of Cultural Heritage for Society ('the Faro Convention'). ${ }^{4}$ It can be seen as a major step to encourage a more inclusive heritage notion, where the promotion of intercultural dialogue is underlined (Council of Europe 2008: 7). The fact that most European countries today have museums that target either colonial history, postcoloniality or immigration history is in itself a sign that museums have addressed the shift in the concerns and priorities of new audiences (Thomas 2010:5,7). Norway is among these countries, and discussions are taking place about the ways in which Scandinavian museums of all types present and represent 'difference'. This may include how ethnicities, cultures and the relationships between colonial settlers and indigenous peoples are represented, which stimulates the discussion about the museums' own institutional practice (Goodnow and Akman 2008).

The role museums play in tackling inequality in their functions as collection and display has been questioned by Sandell ([2002] 2007: 101). Rather than emphasizing the museum's part in excluding, stereotyping or silencing difference in their practice, he turns the question around: In what ways are museums reversing processes of exclusion and othering, to include and to celebrate, rather than stereotype, difference? He underlines the role they play in constructing and disseminating dominant social narratives. What then of the political role that museums might play, alongside other organizations within civil society, in promoting equality of opportunity and pluralist values? With reference to Karp and Kratz (2000), he points to the fact that the construction of cultural identity is achieved through two simultaneously occurring processes. On the one hand identity construction is achieved by the use of exaggerated differences or oppositions that can be alternately a mode of exploration and understanding or an act of discrimination - on the other hand by the use of varied assertions of sameness or similarity between the audience and the object of contemplation (2000: 194).

In the examination that follows, I will actively use the questions raised by Sandell. When comparing the three museum exhibitions, I summarize the similarities and differences with these questions in mind: Do we find a tendency to create 'safe' and uniting narratives that exclude different versions of the past (a sort of 'harmony model'), of the type Harrison and 
Hughes have described (2010)? Or is the situation better described by the process Karp and Katz outlined, as tendencies to either exaggerate (exoticize) the differences, or to underline similarities, that is repress differences?

\section{Three ways of mediating history - choice of methods}

The overarching questions that this museum study deals with are how a pluralistic, diverse and to some extent controversial and disputed past can be mediated by local and regional museums and other relevant actors. Whose cultural heritage is being safeguarded? How is local knowledge in traditions related to Sámi cultural history constructed and mediated in local and regional museums?

The study was carried out in four steps. The first step involved selecting relevant cases. The premise for the choice of museums/cultural centres for this study was a prime location in the South Sámi region. It was considered important because one of the relevant target groups for meditating cultural history in the museum is the Sámi people still living in the area. The fact that there are relatively few museums in the South Sámi region made the selection of relevant cases harder. Although other regional museums have some elements from South Sámi material culture in their collections, their impact areas are geographically larger. Two of the museums/cultural centres finally selected for the study are situated in the northern region of Engerdal in Hedmark County. The third case study is a museum in the South Sámi region on the Swedish side of the national border.

The second step, collecting background information, took place as soon as the final decision about selection of cases for the study were made. Relevant and easily available background information about the museums in question was collected (web information, short informal telephone conversations, etc.), including a literature review of other studies of Sámi museums.

The third step was preparing an informal observation guide. My starting point was to be able to grasp the exhibitions from an outsider's approach. A list of informal questions was made. It included questions like these: When I visit the area for the first time, how much will I get to know of the history of the area when using the museum as a mediator? What objects or information aroused my curiosity, what did I miss and what did I appreciate particularly in the exhibitions I visited? Are certain objects used as identity markers of the South Sámi culture? What ways are the past mediated in the representations: as a view from a contemporary perspective (synchronic) or primarily underlining the longitude of the presence of Sámi in the region (diachronic)? Are cultural and social encounters between different cultural groups in the region mentioned in the exhibitions - and in what forms? Is the concept of ethnicity used particularly in the museums, since ethnicity and the status of the Sámi as indigenous people is an important perspective in societal discourses today, particularly after the establishment of the Sámi Parliament in Karasjok in 1989? How is the relationship between culture and nature mediated? The close relationship between nature and culture has often been a superior perspective in presentations of Sámi adaptation. Is this also striking in these exhibitions?

The fourth step was carrying out studies at site. The three museum exhibitions were visited in 2012-2013. The study of the exhibitions at site involved plainly observing, making notes, taking photos and describing the cases in question. In the presentation of the results and the discussion that follows the three exhibitions will be compared and discussed in the light of each other. The visitor's gaze is a suitable starting point for presenting my impressions of the museums.

\section{Case 1: Blokkodden Villmarkmuseum}

Founding year and prime aim: Blokkodden opened in 1984 and is one of the fairly recent additions to a common museum model in use in Scandinavia, the open-air museum. It is described as 'an outside installation with buildings mainly moved there from elsewhere, with an underlying motivation to inform' (Rentzhog 2007). Blokkodden is dedicated to illustrating former use of nature's resources and the variations the region displays in adaptation and life modes. As a museum situated in a region with a long South Sámi history, its statutes ensure 
that it will have a profile which includes presentations of both Norwegian and Sámi culture and traditions.

Location and layout: The museum is situated in a large recreational area, which consists primarily of flat mountain forest area, situated close to the large lake Drevsjø. Within its borders a series of representative types of dwellings are on display. It intends to show various ways people have survived through times by illustrating different economic forms of adaptation through utilization of resources in the outfields, forests and mountainous areas.

The reception building holds two exhibitions: One is a permanent South Sámi arts and crafts exhibition, where Sámi craft product and tools are displayed. Among the objects

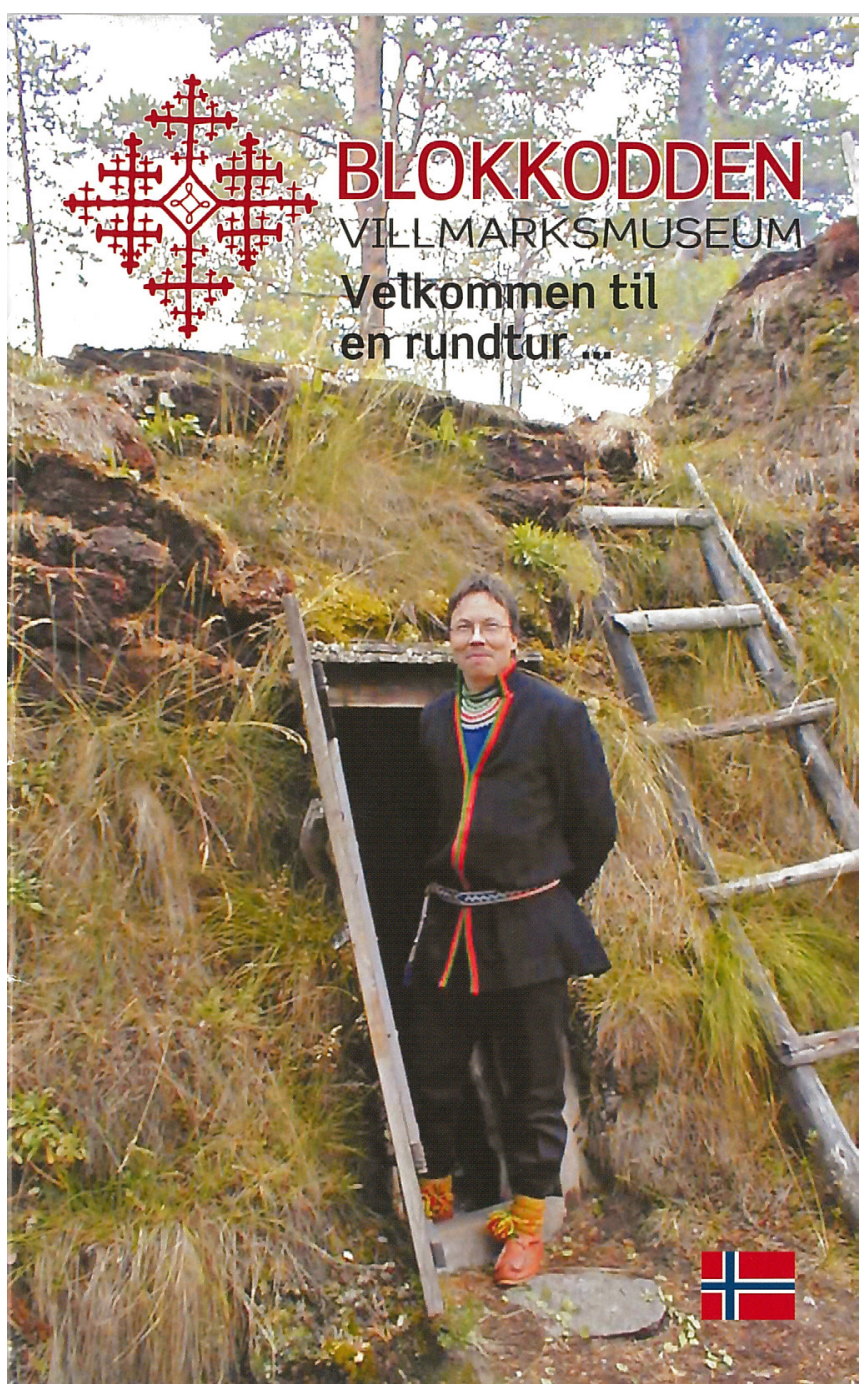

Figure 2. The front page of the museum brochure from Blokkodden Villmarksmuseum, with Jonas Danielsen in front of the gåetie he built. Copyright: Engerdal kommune. multiple ways the natural resources have been used in this region for centuries. Despite the fact that these sites are placed fairly close to each other, they are barely visible among the trees. clothes, footwear, dresses and other textile objects as well as handmade knives. Most of these objects were produced recently and stand as proof that the Sámi art and craft tradition still is thriving. The second exhibition is a black and white photo exhibition that shows the way South Sámi reindeer herding is carried out today. It is the result of a contemporary documentation project.

A large information board at the entrance to the recreational area guides the visitor through the museum area by highlighting the layout and paths. Located in a wide forest area, the museum passes on to the visitors a feeling of the forces of nature and the necessary adaptations people who live and work in this region have made through generations. Well-prepared paths which criss-cross the large outdoor museum area enable the visitors to stroll from one end of the outdoor museum site to the other and still maintain a feeling of wilderness and solitude. A series of various sites (timber logging huts from various periods; stables; outfield huts used for hay storage; a hay drying rack; a moose pitfall; a fishing hut, an installation for falcon catching, a model illustrating how coal mining was done) add information about the exhibited are handmade 

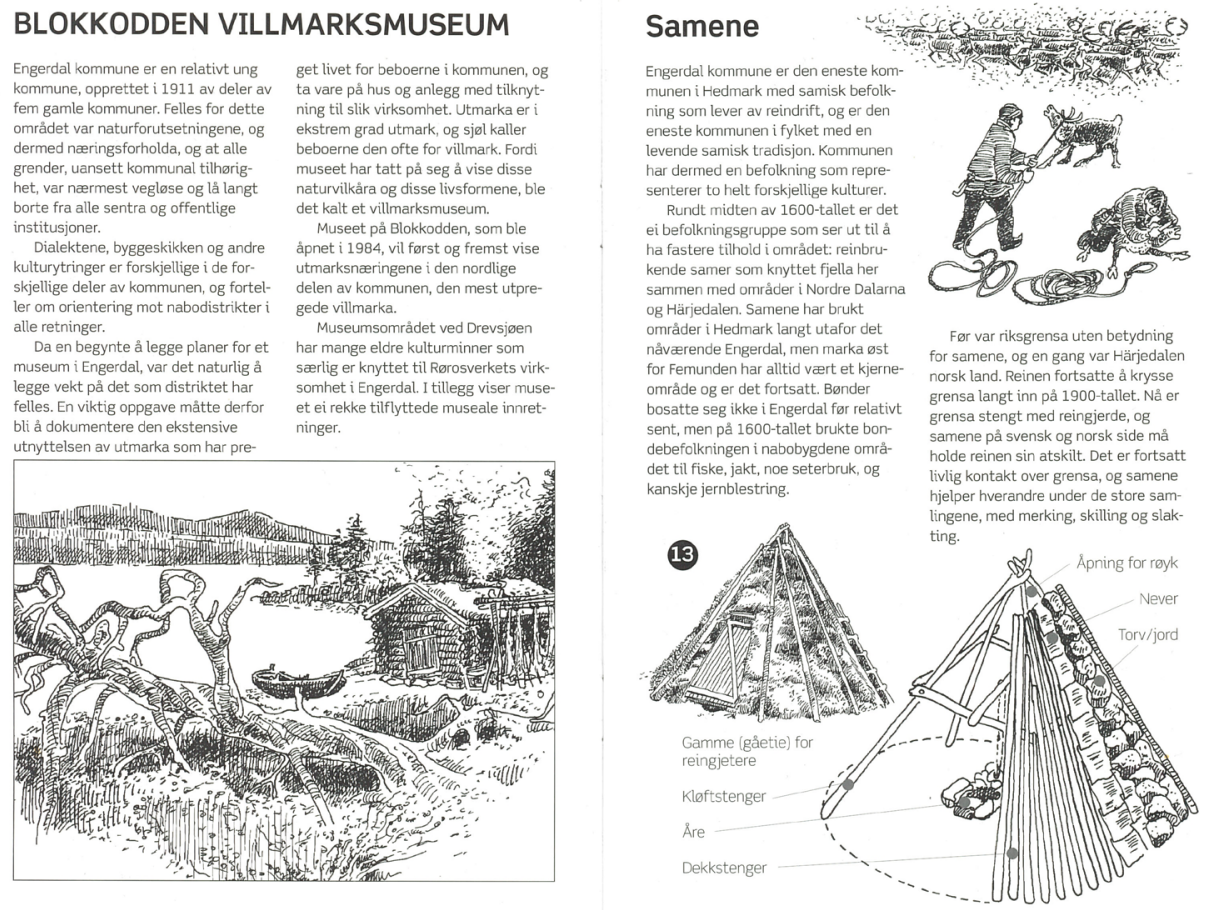

Figure 3. Two pages from the museum brochure from Blokkodden Villmarksmuseum where information about the Sámi history of the region is presented. Copyright: Engerdal kommune

Using the local building expert, Jonas Danielsen, who belongs to one of the Sámi families in Drevsjø, Blokkodden has a Sámi settlement consisting of three buildings as part of the outdoor exhibition: one turf hut (gåetie) for the family, one for the reindeer herders, a loft (warehouse) and a drying rack for meat.

Prime target groups and means of communication: The museum booklet, printed only in Norwegian, is informative and useful for the visitors who choose to walk around the museum alone. On each location or 'information point' in the outdoor museum area an information board is placed which provides supplementary information about this particular site. The text is provided with illustrations, which ensure that the information has a form and length well-adjusted for its purpose. The path is supplemented by a series of signposts along the paths to guide the visitor from one site to the other. The lake is used as a resource to activate the museum visitors in fishing activities, and recently a wharf has been added as a new facility on offer.

It is underlined in the museum's information booklet that this Sámi settlement is not a reconstruction, but is built

the way Jonas Danielsen has learned it from his parents and siblings. He has not tried to turn the clock far backwards. Since it is the snow scooter that made this traditional way of living redundant, the knowledge and tradition about this way of living is still very much alive (Engerdal kommune [1990] 2006).

Ways of portraying the past: The picture that the museum mediates to visitors is that of an adaptation which took place some centuries ago in close contact with nature. No glorified image of 'the good old days' is mediated through the exhibitions, but nor is there any direct mention of conflicts concerning use of the same resources. It is not necessarily undercommunicated, as information is available via the museum leaflet, but it is not underlined. 
No specific attention is paid to whether, how and in what situations face-to-face encounters between different social and cultural groups might have taken place in the past.

\section{Case 2: Femundsmarka Nasjonalparksenter}

Founding year and prime aim. The centre opened in 2005 and was established to bring information to visitors to the region about the nature and culture in the national park area. $A$ national park centre is a relatively new construction in Norway. These centres have several objectives, of which general information is considered the most central. Raising awareness through information was stressed in the white paper which presented the concept early in the 1990s (St. Meld 62, 1992). It points to thematic exhibitions as a means to draw attention to natural and cultural assets in the region as well as the connection between people, nature and landscape. Although the natural park centres are not classified as museums in a formal sense, they share some common features and are encouraged to cooperate with museums and other parties who share the same values (Andreassen et al. 2010: 5).

Location and layout: The rural parish where the national park centre is located is named Elgå. It consists of a cluster of houses, including a parish church and two motels that are situated few hundred metres further north of the national park centre. They are all placed close to the lake Femunden with a great panorama across the lake and surrounding mountain areas. The museum itself is built in an architectural form that evokes clear associations of the turf hut (gåetie), the dwelling of the South Sámi, which makes it stand out from the rest of the buildings in the cluster. A large information board is put up outside the entrance to the National Park Centre, providing information to visitors about the botany and fauna characteristic of this area, as well as some data about the neighbouring national park of Gutulia.

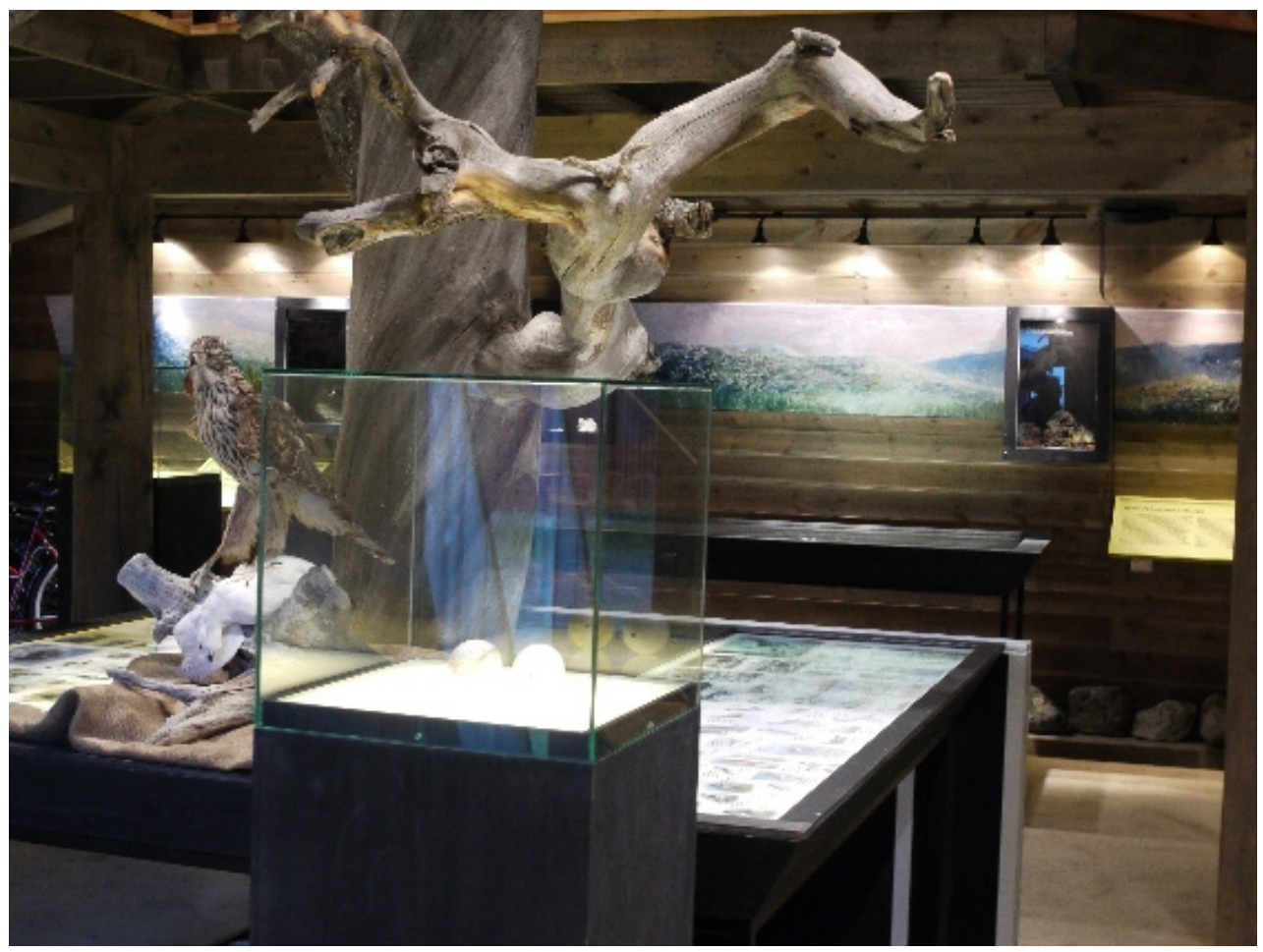

Figure 4. Photo showing the centre of the exhibition of Femundsmarka National Park Centre. Photo: Grete Swensen, NIKU 


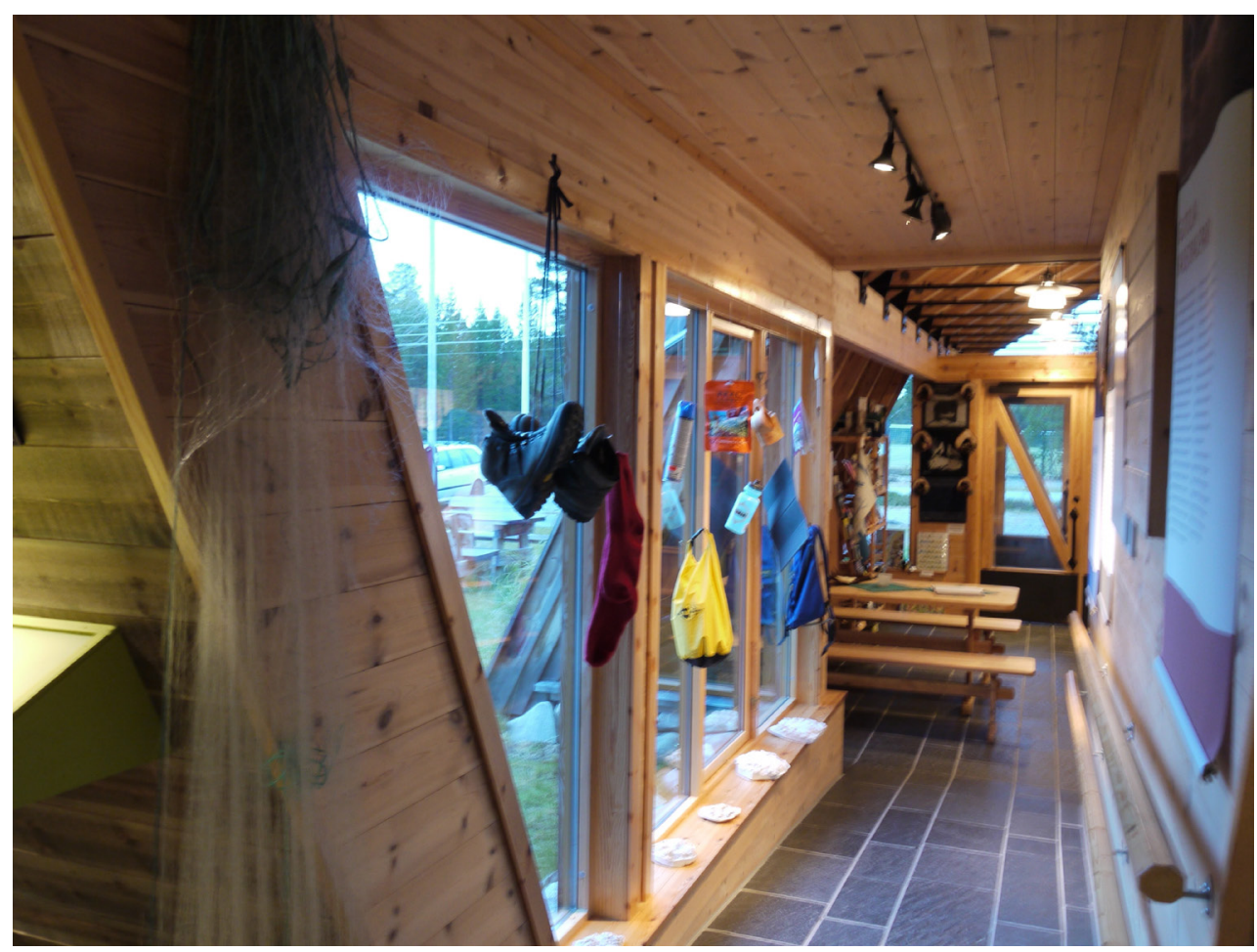

Figure 5. Photo showing parts of the hallway where modern tourgear is exhibited in the windows of Femundsmarka National Park Centre. Photo: Grete Swensen, NIKU.

Prime target groups and means of communication. The museum exhibition was produced in cooperation with professionals from Norsk Skogmuseum which is located in Elverum, one of the main towns in Hedmark County. The exhibition is organized as a combination of information boards and display cabinets, and includes relatively few, but informative objects, most of them being of relative recent origin. They are selected to portray a long history of cultural adaptation in this region, and there are objects which give clear connotations of the Sámi adaptation, as well as tools and machinery from contemporary motorized forestry work. The permanent exhibition includes a series of themes, presented in roughly chronological order: It starts with a presentation of the landscape, followed by a display cabinet addressing 'The Hunters'. The topics to follow are: Mining activities; Agriculture and forestry; The South Sámi; Reindeer husbandry today; From generation to generation; Animals; Plants; Hunting; Fishing and Boat traffic. The last two displays relate to the area's present status as national park and discuss the effects of tourism on the area. A mezzanine in the exhibition hall holds a gallery with changing exhibitions, including a reading corner for children. When I visited the national park centre late summer 2012, the exhibition on the mezzanine portrayed a local Norwegian recluse and recognized storyteller named Store-Hans. He is the only named person in the exhibition.

Ways of portraying the past. The coexistence of the Sámi and the Norwegian in the Femundsmarka region is given a considerable degree of attention throughout the exhibition, despite the rather restricted exhibition space at hand. Concerning the cultural history of the area, however, it raises more questions than it answers: The section about 'The Hunters', which is the part of the exhibition where the long history of cultural encounters is addressed, leaves room for many personal interpretations: Who were the hunters? Were they of Sámi origin, of Norse origin, or were they hunters and gatherers on the move from southern parts of Scandinavia? The long history of the region is left in a haze. The visitor is left with an image of a region with coexisting but parallel and independent life modes. Face-to-face cultural encounters between indigenous and settlers are not mentioned. 


\section{Plan över utställningen en trappa upp}

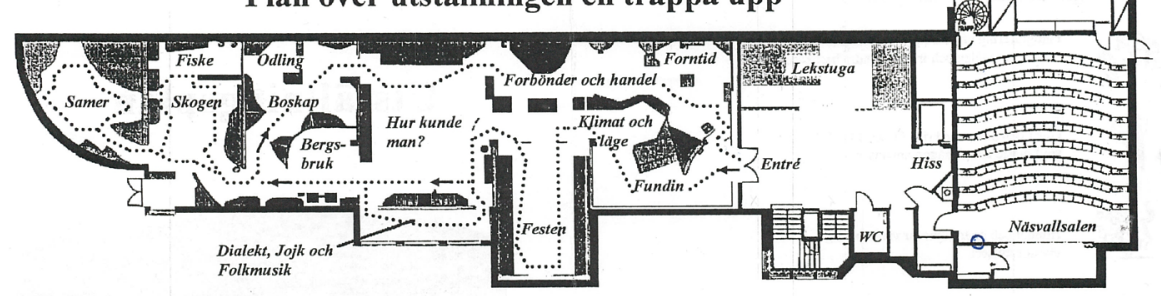

Något om vad Fjällmuseet kan erbjuda...

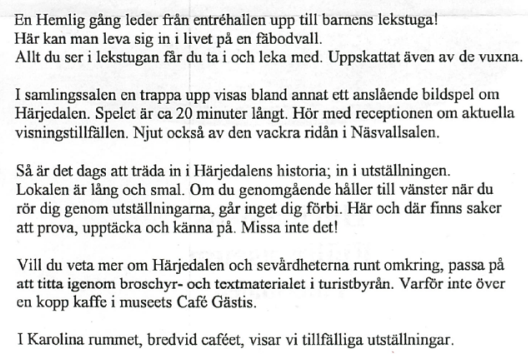

I Karolina rummet, bredvid caféet, visar vi tillfälliga utstälningar.

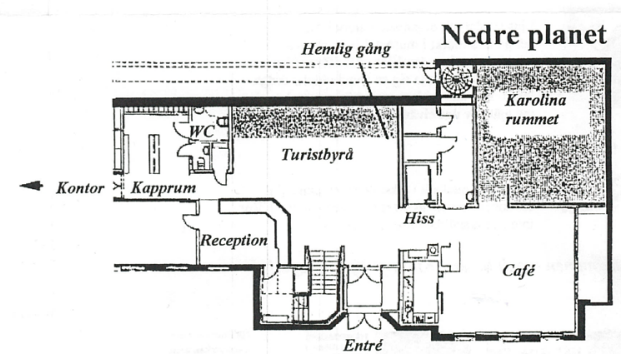

Figure 6. Plan showing the layout of the ground and first floor of Härjedalens fjällmuseum, with the main exhibition hall on the left. Copyright: Härjedalens fjällmuseum.

\section{Case 3: Härjedalens fjällmuseum}

Founding year, location and layout. The museum is situated in the parish of Furnadal in Härjedalen Municipality, located in Mid-Sweden. The museum collection goes back to 1894 and is owned by a foundation owned by Jamtli, Härjedalen Municipality and Härjedalen Society of Antiquities. Today the museum consists of an open-air museum with 34 buildings, and a main museum building erected in 1999, which accommodates permanent and temporary exhibitions as well as service functions (playroom, restaurant, film auditorium etc.). The museum received the European Museum of the Year award in 2001.

Prime target groups and means of communication. The exhibition that is presented here is the permanent exhibition situated on the first floor in the main museum building. At the entrance to this exhibition a list of names of professional advisers is presented, four of whom were members of a Sámi reference group.

The exhibition consists of a series of 13 tableaus (sections). The visitors are advised in the museum leaflet to keep to the left side in the exhibition.

Then the visitor will approach the remaining 12 tableaus in this sequence: Climate and topography - celebrations - dialect, joik and folk music - mining activity - Sapmi - the forest - fishing - cultivation - livestock - life modes and utilization of resources - farmers and commerce - prehistory (see fig. 6). The first tableau presented to the visitor was titled 'Faces from Härjedalen'. It presents six portraits painted by the artist Bengt Ellis, of which four bear titles (The Hunter, Portrait of an Old Farmer, The Forest Worker and The Forest Recluse).

There are texts and photos later where the main theme of the exhibition is underlined, which is to tell the history of the three cultures that have lived side by side in this region: the farmer, the mine worker and the Sámi.

The tableau titled 'Sápmi' is the sixth tableau of the series of 13 and is situated at the end of the exhibition hall (Sápmi is the traditional name for the Sámi homeland). The curved wall and the dark wood ceiling immediately arouse distinct associations of the inside of the turf hut 
(gåetie). Various means are used to disseminate information, one of them being display cabinets with objects such as tools and crafts, another is an installation made of wood and shaped like 'books' with sheets, where the information is presented in both Swedish and Sámi. There are a total of four such installations, each raising questions such as: 'Where is the Sápmi homeland situated? Is a Sámi village a village? How do Sámi live today?' While strolling around we learn that 'The Sámi culture was sparse in objects [...]. But rests on richness in knowledge'. There is information about the relationship to the landscape, illustrated with the seasonal reindeer movements in accordance with available pasture. The presentation is personified by the use of many photos where the names of the people portrayed are mentioned. One of the strongest devices is a film collage presenting a long series of portraits from everyday life. Provided with a substantial amount of the total floor space of the exhibition and placed in the middle of the sequence of the 13 tableaus, available tools are evidently used to present the Sámi section as an integral part of the main exhibition. It still stands out as divided and separated from the rest, however. This impression can be caused by several factors related to the chosen exhibition design (for instance a rather narrow entrance into the tableau, the dark ceiling which is only used in this part of the exhibition etc.).

The forest tableau tells the story of conflicts which arose between newly arrived farmers who needed fenced-in pasture for their livestock and Sámi who had lived long in the same area with their reindeer herds. This is primarily where information about difficult periods of cultural encounters are brought up.

The prehistory section at the end of the exhibition consists of a mixture of text, exhibited archaeological finds as well as reconstructed objects. On a print showing rock art, we learn that 'Sámi and mountain farmers have lived side by side in the region for 1000 years. But there are traces of people here for 8000 years.' Another presentation tells us that

'For a long time it was believed that the people living in Härjedalen in the Iron Age were Nordic. But in the mountain area named Vivallen findings have shown distinct Sámi traces. About 900 years ago the Nordic and the Sámi culture met in the western part of Härjedalen'.

Ways of portraying the past. The coexistence of three life modes in the region is presented as the main theme of the exhibition. Although definitely present, they do not play an equal role. The material richness of the Swedish farming culture has partly managed to drown out the two other life modes. It manages to create exoticized images of all three, and particularly by unintentionally polarizing the Sámi nomadic and the Swedish farmers' life modes. Cultural encounters of the past are mentioned, and conflict of interests is a theme which occurs from time to time. But it is a very compressed and information-rich history the visitors have to relate to.

\section{Discussion}

\section{Summary of the tendencies}

There are certain similarities in the way the pluralistic past in the region is portrayed in the three museums. There is a general tendency to describe the presence of the Norse and the Sámi population in the region in neutral, i.e. passive impartial terms. If we go far enough back in history, however, the distinction between the two ethnic groups tends to get blurred. The presentation is done primarily without attaching importance to the various arenas of social interaction that must have existed throughout the thousands of years the two ethnic groups have existed side by side. The impression the visitor is left with is that this is a region where two ethnic groups have lived side by side, but in isolation and without much contact. There might be several reasons behind this omission: The cultural encounters are either interpreted as a self-evident phenomenon and therefore not necessary to pinpoint specifically - or it is considered beneficial to leave out former periods of 'dissonance' (Tunbridge and Ashworth 1996) and put most weight on recent well-adapted co-existence. There are of course nuances to this general description, and it should be underlined that conflicts between the Swedes and the South Sámi population concerning rights to land are mentioned in passing in Härjedalens fjällmuseum (for more information, see Zachrisson 2004). If we now return to the initial question 
raised in this study, whether the history is neutralized, exoticized, or repressed, I would lean towards the first version - a neutralized, i.e. passive impartial version of history. Very few incidents of conflict are mentioned. Taking into consideration what a 'hot' political theme the right to grazing land is in this region, it is possible to interpret this as a (perhaps unconscious) way of neutralizing or harmonizing a history that in periods has been experienced as oppressive.

\section{The use of objects as identity markers}

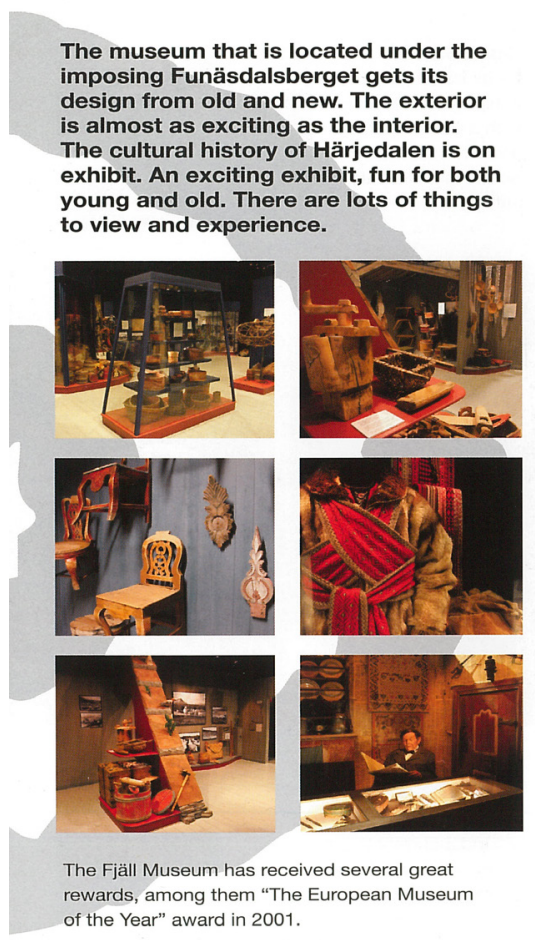

Figure 7. A page from one of Härjedalen Fjällmuseum's leaflet, showing parts of the main exhibitions. Copyright: Härjedalens fjällmuseum.
I will now turn to the way the objects are used in the exhibitions and what messages they mediate. Is there a basis to state that certain objects are used as identity markers in the exhibitions? Concerning the use of identity markers, the differences between the three museums become evident. Blokkodden is an open-air museum with limited indoor space for exhibitions, which strongly influences which objects can be displayed, and as pointed out, the main exhibition in the reception area is an Arts and Crafts exhibition. In the National Park Centre, with limited space available; only a few museum objects are borrowed and they are intended to play a subordinate role, primarily for visual effect. They are styled as installations and fill the purpose of bringing variation: for instance stuffed birds, antlers as well as a recently produced outfit for walkers, a river boat and fishing nets. They play an integral role in combination with the text boards, large photos and a few glass showcases. In Härjedalens fjällmuseum both daily life and ritual celebrations in the peasants' life are illustrated through a rich collection of objects, while the South Sámi part of the exhibition is organized in a way which invites the visitor to participate more directly in the learning process.

Despite the fundamental differences in the way the objects are displayed, we find one object which can be described as a common denominator. The object that the three institutions have chosen independently of each other as a symbol is the turf hut (gåetie). Rather than being a museum artefact in a traditional museum sense, i.e. part of a museum collection, this is a reconstruction of a building that carries major importance. Although it holds a certain resemblance to the turf buildings used by Sámi further north, it is distinct in that it combines two parts: a lower entrance part and a larger circular building. Since many South Sámi today have settled permanently, there are few of these dwellings left. They were built of wood and turf which are natural materials which decompose rapidly. The hearth is one of the few remains which to the expert eye of the archaeologists have stayed visible in the landscape through time. It is shaped in a particular way, and the order in which the family members were positioned around the fireplace was determined by custom. Today these remains of the hearth give important information to archaeologists and cultural historians about the South Sámi way of life.

The turf hut (gåetie) is used as a mediator in different ways in the three museums. In Blokkodden it is placed in the outdoor museum as one of a series of dwellings which belong to the region. In addition a modern meeting hall is built in Blokkodden close to the reception building which evokes certain associations with the turf hut (gåetie). While it is 


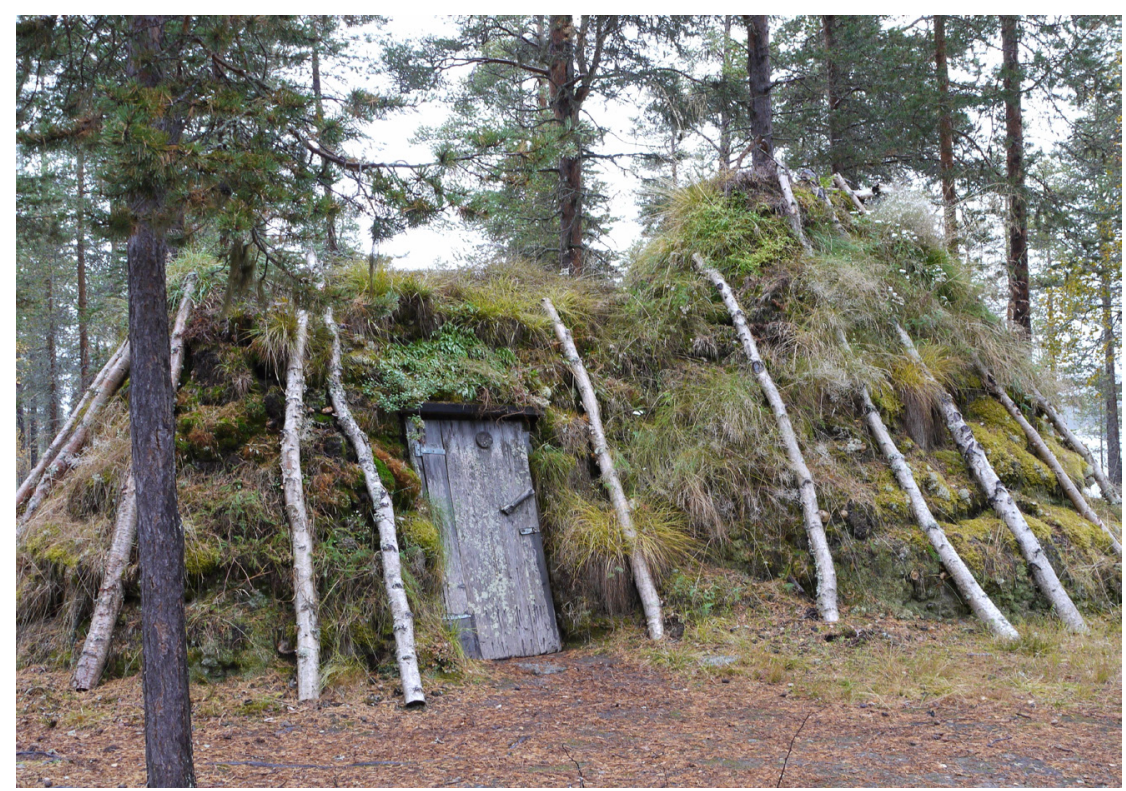

Figure 8. The gåetie and other buildings of the South Sámi settlement are integrated in the outdoor museum at Blokkodden alongside a series of buildings illustrating various adaptations in the region (cottages for forest workers, outfield huts for hay storage, fishing hut). Photo: Grete Swensen, NIKU.

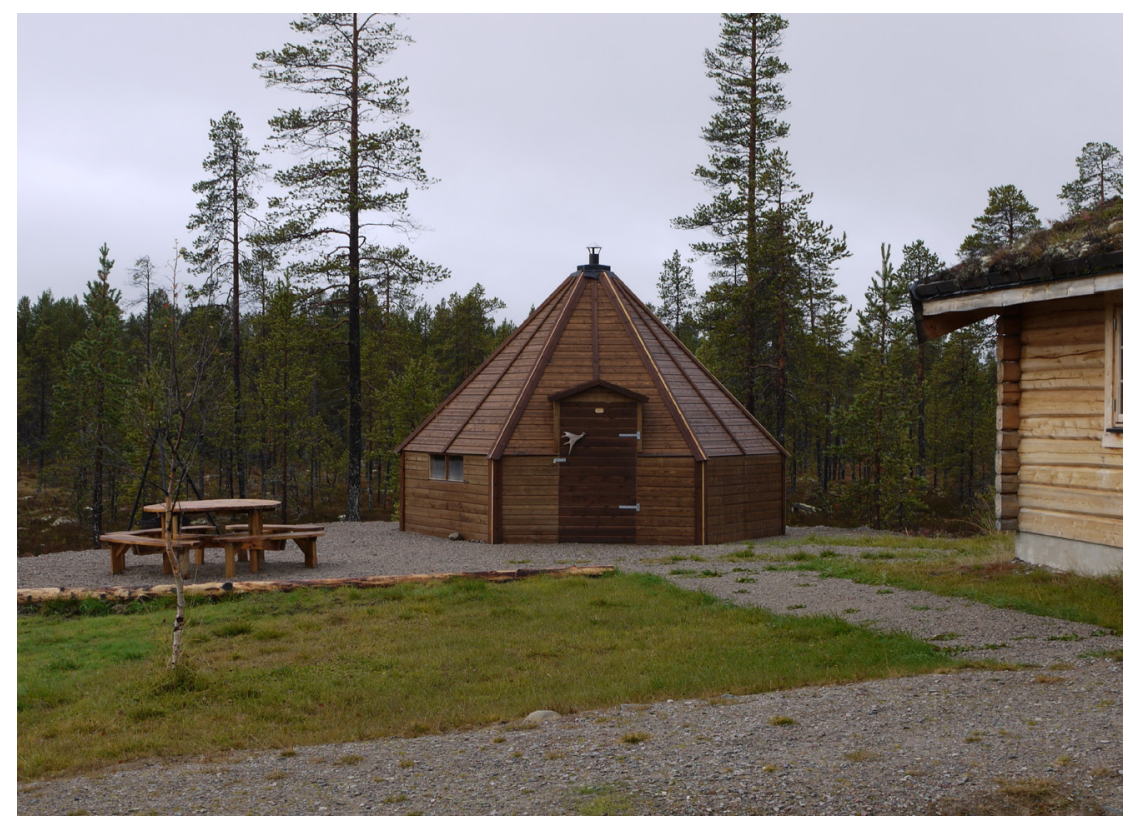

Figure 9. A building recently erected close to the museum reception at Blokkodden arouses associations to the gåetie. Photo: Grete Swensen, NIKU. 
integrated as an element in the outdoor museum in Blokkodden to mediate the traditional South Sámi way of living, it is used in both the National Park Centre and Härjedalens fjällmuseum as an implicit motif for the architects who designed the main museum buildings. A combination of circular and the rectangular building forms and mixed uses of wood and turf give distinct associations in this direction.

If asked whether certain objects are used as identity markers in the exhibitions, it would be the way the turf hut (gåetie) is used to draw attention to cultural differences that have existed in these places. In the exhibition in Härjedalen the abundance of objects in the peasant household compared with the sparseness among the South Sámi is striking - maybe unintended and partly caused by the origin of the museum as a private collection. It profiles the Sámi as a people close to nature. Except for the sound room, where the visitors can listen to the different dialects and languages of Härjedalen, it intends primarily to portray The Past as a historic stage long since vanished. A visitor to the exhibition does find some references to present-day society, but the general impression is one of a static society, both the Swedish and the Sámi. In other words not many references are given which can enable young people to identify with the way of life profiled here. It is primarily a constructed past that is reflected in the exhibition. This imbalance is not annulled through the films played in the auditorium next to the exhibition hall, since the films are rather ahistorical in their references to cultural encounters in the region. There are more references to modern life in the two Norwegian exhibitions (photo exhibition of modern reindeer herding and integration of modern pieces of garments and shoes from outdoor recreational life).

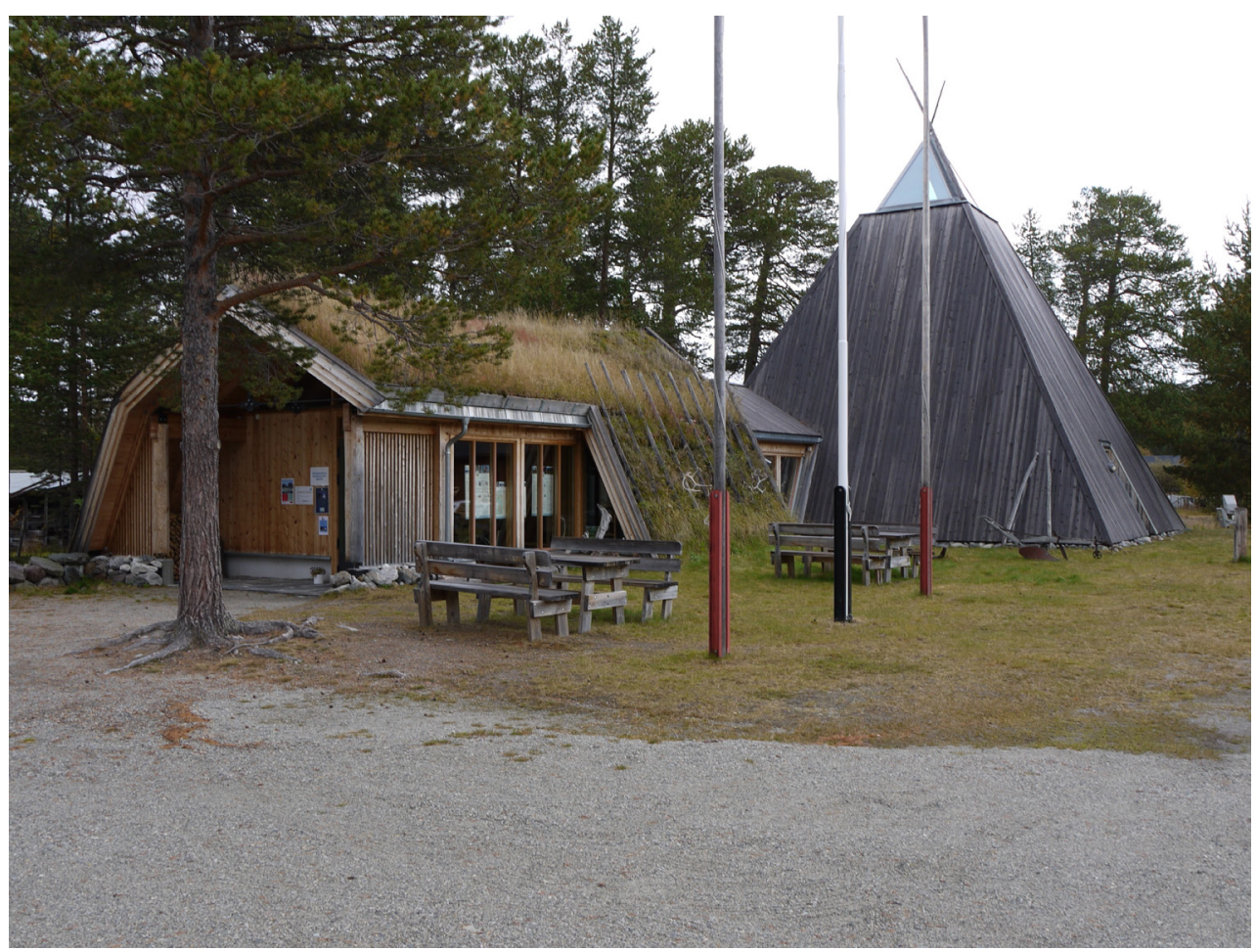

Figure 10. Femundsmarka National Park Centre was built in 2005 and is designed with the gåetie as a model. Photo: Grete Swensen, NIKU. 


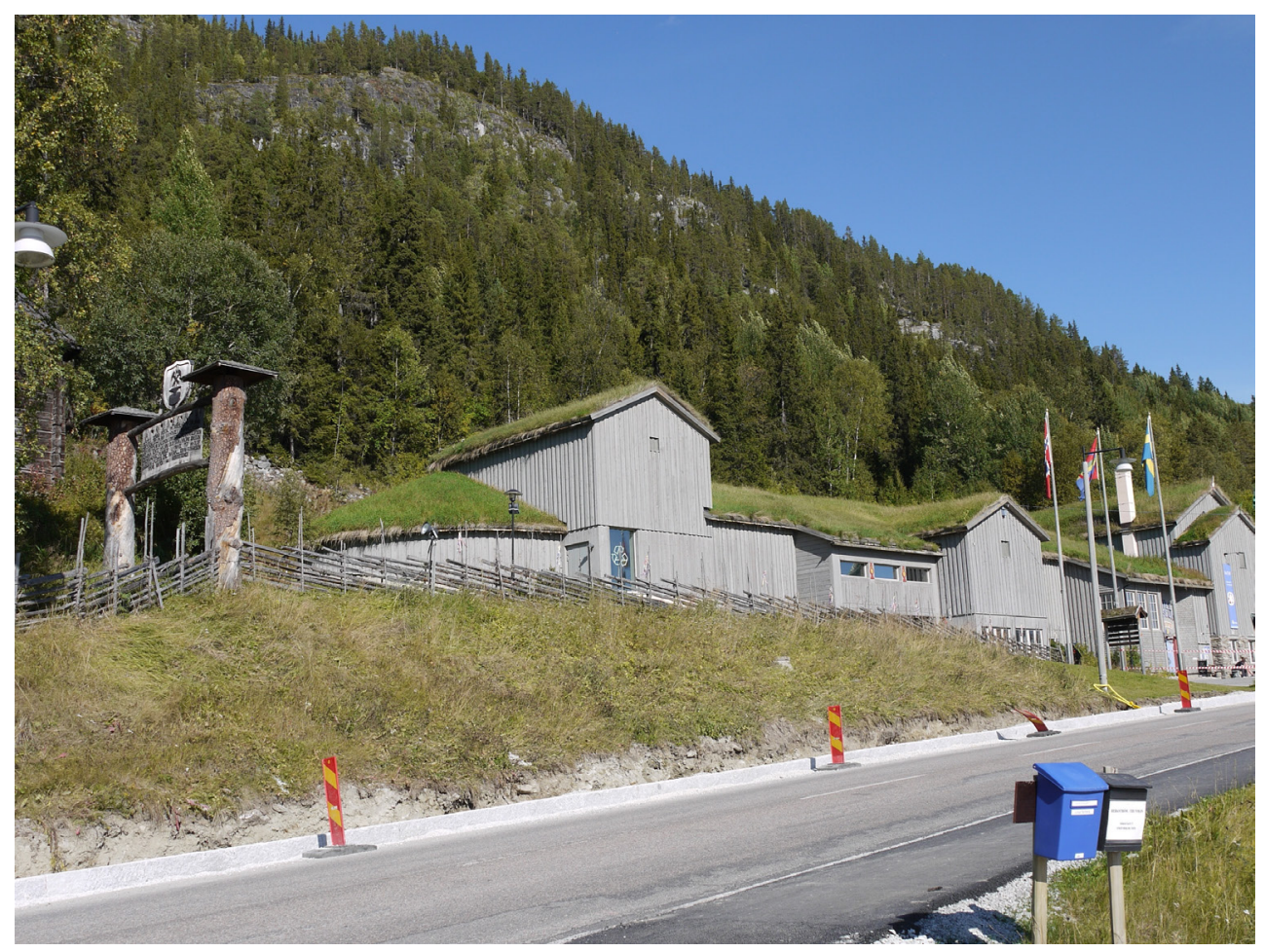

Figure 11. Härjedalens fjällmuseum's museum building was erected in 1999 and combines regional building materials such as wood and turf. The circular part of the building to the left is the hall where the South Sámi section is situated. Photo: Grete Swensen, NIKU.

\section{Other studies of Sámi exhibitions}

It is interesting to view these findings in relation to other museum studies that have been carried out in the northern region of Norway. In a thorough analysis of representation of Sámi museum exhibitions conducted by Olsen (2000), he asks to what extent the large growth in new national, local and 'ethnic' museums contributes to the production of alternative representations. Are the representations we meet different when an indigenous community formerly represented by others has gained an option to model their own versions of their culture and history? Or is this picture still based on an inherited repertoire of outsiders' categories in a way that ends up with a reproduction of old stereotypes (Olsen 2000: 14)? Olsen concludes his examination of three exhibitions that the exhibitions rest on the idea of Sámi culture as something static and original before being polluted by contact with the modern, a myth kept alive about Sámi societies which have been in continuous change.

Another study of representations of the Sámi in the earliest exhibitions in majority museums in Norway and Sweden has reached similar conclusions (Mathisen 2011). How choices of spatial distribution, illustrations, lighting, colour schemes and exhibition texts can lead to implicit misrepresentations of the Sámi pasts in a museum exhibitions, has been illustrated by Spangen (2015) in a study of an exhibition in the Swedish History Museum from 2005 (Spangen 2015: 22,23). Webb (2006) found that a change had occurred between the older and the more recently established museum collections. Her study included eight museums defined as Sámi. She observes a common lack of sense of time or of change through time in the museums which were first established. Reindeer and nomadism are elements that make prominent the difference between Sámi and non-Sámi. 'The overwhelming impression of Sámi culture in these indigenous museums is that it is timeless and static - a traditional people living in harmony with nature, utilizing it, but maintaining balance' $(2006: 173,174)$. The more recent 
museums, however, those that had opened from the late 1990s onwards, have created quite different representations. She found they relate to people's lives; 'a collective identity that was instantly recognizable and one which would make them proud to be Sámi again' (2006: 175).

\section{Possible explanations for the differences}

There might be several reasons for the general tendency to describe the co-presence of the Norse and the Sámi population in neutral, i.e. passive impartial terms. A partial explanation for the differences can be found in the limited resources that small and medium-sized museums have available. Small and medium-sized are here defined as museums or cultural centres with the number of employed professional ranging from none to five. The first point I would underline is purely practical and organizational conditions. The museums in question here are local and partly run on a voluntary basis. Limited resources concerning available exhibition facilities and permanent professional staff influence these museums. In addition they have to relate to the common museum challenge: the need to communicate a message, which requires simplification. It will always represent a balancing act because many vital nuances easily get lost. Simplification can be done consciously, but just as often it is done subconsciously (see Karp and Kratz 2000, ref. in Sandell 2007a). Many contemporary museums are concerned about making their exhibitions relevant to people today, by relating to the conditions in which people live and current political questions. This highlights the challenge museums face when mediating history: it has to be written in capital letters. This can lead to situations where periods dominated by friction and conflict have been forgotten or suppressed.

\section{Involving user groups: possibilities and limitations}

We can ask what alternatives can be suggested as ways to counteract the limitations such small-scale local museums are experiencing. Today involving user groups are often seen as an important way of ensuring that the messages reach the intended target groups and are experienced as relevant by the local community and a wider society. All the three museums/ cultural centres have to a certain extent involved representatives of the Sámi people in the preparation of the exhibitions. The well-recognized artisan and craftsman Jonas Danielsen played a key role in building the Sámi dwelling in the outdoor museum at Blokkodden, besides having a vital role when the museum guide was written. He is pictured on the front page of the museum guide in front of the turf hut (gåetie) he has built. In the executive committee for the National Park Centre at least one of the representatives belongs to the Sámi people. In Härjedalen there is a reference group appointed to ensure that the mediation of the history and culture of the Sámi in the region is carried out. This involvement has left definite traces in the exhibitions, for instance in the form of stories and songs (joik) recorded in Sámi. Sharing knowledge is important to promote dialogue and cooperation. It is important, however, to be reminded that in most local communities there exist hidden power relations that can influence the forms of cooperation which take place. They can affect how freely exchange of ideas and views can take place and influence the creative process of producing an exhibition. This should not prevent initiatives from being taken, but it is an important factor to take into consideration when the final product is being evaluated.

There is a series of ways in which museums have tested different forms of user involvement in their activities. More use of digital media is opening up new methods of engaging members of source communities in museum activities, also when the cultural institutions are localized elsewhere (Srinivasan et al. 2010). In this way the museums have contributed towards using and safeguarding the knowledge and experiences which are available in the local communities (Watson 2007; Golding and Modest 2013). It can offer stimulating experiences to the visitors and help to strengthen their local anchorage. At the same time the frameworks in which these institutions work are tough. It requires large proportions of creativity to work within relatively restricted economic resources. When concluding this critical evaluation of three museum exhibitions it is important to call attention to the following point: When ideas and good intentions are being generated, there always comes a stage later in the process where the ideas have to be reconsidered and a reality check made to enable a solid foundation in the economic realities of the museum. 


\section{Conclusion}

The study of the three exhibitions has shown that the way the past is mediated in this South Sámi and Norse borderland leaves a fragmented picture and rarely touches on the question of how social encounters have taken place between neighbouring ethnic groups. It leaves an impression of a situation where the multiple and complex past in the South Sámi region has either been reduced to some form of 'timeless past' distinctly different from the modern present, or a form of shared 'far away past' as fishers and hunters. The knowledge of the region's history has continuously been widened and new perspectives have been added through studies in archaeology and cultural history (see Appendix). A more inclusive understanding of cultural history and heritage is necessary, where the dynamics of social interaction hold an indisputable place. A more nuanced picture can widen the general local historical understanding. Some museum curators may hesitate to mediate difficult and problem-oriented, potentially controversial exhibitions because they fear negative reactions from the public. A way to engage and raise new questions among the visitors is to present parallel histories. Logan (2010) has described situations

where cultural heritage is "divided" between different ethnic and socio-economic groups. It leads to situations where different groups demand a right to the same places, objects and sometimes experience-based knowledge as part of their own cultural heritage; this is a situation that to a certain degree is universally experienced (Logan 2010).

Telling parallel histories can be a way of mediating history that succeeds in raising new questions among museum visitors: Are some voices more important - or more believable or reliable than others? Who do we take into consideration? Such questions are important to raise continuously. By presenting different interpretations of history side by side, the exhibitions hold the potential to inspire and encourage discussions and exchange of opinions. It may contribute to strengthening cultural understanding and enlightenment, which is particularly important in an increasingly transcultural society.

\section{Appendix}

The museum study is part of the research project "Cultural history, cultural heritage management and mediation in a South Sami and Norse Borderland", funded by the Research Council of Norway (2012-2015). Its central objectives have been to systemize, interpret and analyse the cultural heritage material from the Early Stone Age up until the 16-1700-century, a time span covering more than 9000 years. The project is also questioning the way current public management acts in relation to cultural heritage sites of different ethnic affiliations as well as how the Sámi and Norse field is mediated in the museums. The study of long-time cultural history has identified both continuities and changes in many aspects of culture and society. Through time, two leading patterns seem to be present. In the Late Neolithic and Bronze Age, the material distribution reflects contemporary cultural traditions, consisting of mainly two groups with connections to different geographical areas and peoples outside the study area (Amundsen 2003, 2011). In the Iron Age and the Middle Ages (Bergstøl 2004, 2008) as well as in recent historic times (Braseth 2014, Fjellheim 1999, 2012) there is another tendency consisting of a mixed or hybrid material culture of Sámi and Norse elements within the same landscapes. The main patterns, and the inherent processes of change, suggest that Rendalen and Engerdal in the inland of south-eastern Norway was one of several regions constituting both a border and, later on, a meeting point between early Sámi and Norse identities. Among other factors, the different landscapes, with natural borders and different natural conditions, might have a major meaning for the diversities in the cultural historical development. Contacts and impulses from adjacent and even more distant regions were important factors as well. 
Received: 11 December 2015

Finally accepted: 3 July 2017

\section{Notes}

1 This museum study is part of the research project 'Cultural history, cultural heritage management and mediation in a South Sámi and Norse Borderland', funded by the Research Council of Norway (2012-2015). Its central objectives have been to systemize, interpret and analyse the cultural heritage material from the Early Stone Age up until the seventeenth and eighteenth centuries (for more information, see Table 1). Results from other parts of the research project have been published in Skjeggedal \& Overvåg 2017

2 Härjedalens fjällmuseum website: http://www.fjallmuseet.se/ [accessed 19 June 2013]

3 The professional definition of 'museum' most widely recognized today is still the definition given in 2007 in the Statues of the International Council of Museums (ICOM): 'A museum is a non-profit, permanent institution in the service of society and its development, open to the public, which acquires, conserves, researches, communicates and exhibits the tangible and intangible heritage of humanity and its environment for the purposes of education, study and enjoyment.' It replaced the old definition from 1974 (Desvalles et al. 2010: 57).

4 The Faro Convention, Faro, 27/10/2005; The Framework Convention on the Value of Cultural Heritage for Society http://conventions.coe.int/Treaty/EN/Summaries/Html/199. htm. [ Accessed 15.5.2010]

\section{References}

ABM utvikling (2006) BRUDD. Om det ubehagelige, tabubelagte, marginale, usynlige, kontroversielle. Oslo: ABM Utviklings Skrift 26.

Amundsen, H.R. (2003) 'Cultural Traditions and Ethnic Relations in Late Neolithic and Bronze Age in Hedmark County, the Interior of Eastern Norway', in J. Bergstøl (ed) Scandinavian archaeological practice - in theory. Proceedings from the $6^{\text {th }}$ Nordic TAG, 166-177, Oslo Archaeological Series (1), Oslo: University of Oslo.

(2011). Mot de store kulturtradisjonene. Endringsprosesser fra tidligneolitikum til førromersk jernalder mellom Mjøsa og Femunden. Ph.D.-avhandling, Institutt for arkeologi, konservering og historie, Det humanistiske fakultet. Universitetet i Oslo.

Amundsen, H. R. and Os, K. (2012) 'Cultural History, Cultural Heritage Management and Mediation in a South Sami and Norse Borderland - A New Norwegian Research Project.' Paper presented at EAA, Helsinki, unpublished paper.

Andreassen, I.; Fredreheim, G.E.; Magnussen, T. and Sandberg, A. (2010) Nasjonalparksentrenes funksjoner som naturveileder, reiselivsaktør og nasjonalparkinformatør. NF-notat nr. 1004/2010, Bodø: Nordlandsforskning.

Angelis, A.D., Ianniciello, C., Orabona, M. and Quadraro, M. (2014) 'Introduction: Disruptive Encounters - Museums, Arts and Postcoloniality,' in Angelis, A.D., lanniciello, C., Orabona, M., Quadraro, M. and Chambers, I. (eds.) (2014) The Postcolonial Museum: The Arts of Memory and the Pressures of History, 1-25, Farnham: Ashgate.

Barrett, J. (2010) Museums and the Public Sphere. Chichester: Wiley-Blackwell.

Bennett, T. (1995) The Birth of the Museum: History, Theory, Politics. London and New York: Routledge. 
Bergstøl, J. (2004) 'Creols in Iron Age Norway?' in Hakenbeck, S.E. and Matthews, S.G. (eds) Archaeological Review from Cambridge 19 (2). Reconsidering Ethnicity. Material Culture and Identity in the Past, 7-24.

(2008) Samer i Østerdalen? En studie av etnisitet i jernalderen og middelalderen $i$ det nordøstre Hedmark. Acta Humaniora nr. 325. Diss., Det humanistiske fakultet, UiO. Oslo: University of Oslo.

Braseth, L. (2014) Samer sør for midtnattsola. Sørsamenes historie, kultur og levemåte. Bergen: Fagbokforlaget.

Clifford, J. (1997) 'Museums as contact zones' in Clifford, J. (ed) Routes, travel and translation in the late twentieth century, 188-219, Cambridge, Mass.: Harvard University.

Council of Europe (2008) Heritage and beyond. Strasbourg: Council of Europe Publishing.

Connerton, P. (1989) How societies remember. Themes in the social sciences. Cambridge: Cambridge University Press.

Desvalles, A and Mairesse, F. (eds.) (2010) Key Concepts of Museology. ICOM, Armand Colin. http://icom.museum/professional-standards/key-concepts-of-museology/ (accessed 31.8.2016).

Engerdal kommune ([1990] 2006) Blokkodden Villmarksmuseum. Velkommen til rundtur. Tynset: Engerdal kommune.

Fjellheim, S. (1999) Samer i Rørostraktene. Eget forlag.

(2012) Gåebrien sitje - en sameby i Rørostraktene. Eget forlag.

Golding, V. and Modest, W. (eds) (2013) Museums and Communities. Curators, Collections and Collaborations, London, NEW YORK: Bloomsbury.

Harrison, R. and Hughes, L. (2010) 'Heritage, colonialism and postcolonialism', in: R. Harrison (ed.) Understanding the Politics of Heritage, 234-269, Manchester: Manchester University Press

Hooper-Greenhill, E. (2007) 'Education, post-modernity and the museum' in Knell, S. J., MacLeod, S. and Watson, S. Museum revolutions: how museums and change and are changed, 367-377, London and New York: Routledge.

Karp, I. and Kratz, C.A. ([2000] 2011) 'Reflections on the Fate of Tippoo's Tiger: Defining Cultures in Public Display' in Hallam, E. and. Street, B.V (eds) Cultural Encounters: Representing 'Otherness', 194-225, London and New York: Routledge.

Kidd, J., Drago, A., Ryall A. and Stearn, M. (2014) Challenging History in the Museum. International Perspectives, Farnham: Ashgate.

Kirschenblatt-Gimblett, B. ([2004] 2012) 'From Ethnology to Heritage. The Role of the Museum', in B. M. Carbonell (ed) Museum Studies. An Anthology of Contexts, $2^{\text {nd }}$ edition, 199-205, Chicester: Wiley-Blackwell.

Langfield, M; Logan, W. and Craith, M.N. (eds.) (2010) Cultural diversity, heritage and human rights: intersections in theory and practice. Key issues in cultural heritage, London: Routledge.

Logan, W and Reeves, K. (eds) (2009) Places of pain and shame: Dealing with 'difficult heritage', London: Routledge. 
Lynch, B. (2014) 'Uncomfortable Histories and Current Museum pPractices', in Kidd, J., Drago, A., Ryall A. and Stearn, M. Challenging History in the Museum. International Perspectives, 87-100, Farnham: Ashgate.

Macdonald, S. (2013) Memorylands, Heritage and Identity in Europe Today. London and New York: Routledge

Mathisen, S. O. (2011) 'Northern Borderlands and the Authentics of Ethnicity. Intervisuality and the Representations of the Sami in Early Exhibitions at National Cultural Museums in Norway and Sweden', Arv. Nordic Yearbook of Folklore (67), 57-72.

Olsen, Bjørnar (2000) 'Bilder fra fortida? Representasjoner av samisk kultur i samiske museer', Nordisk Museologi, (2) , 13-30.

Onciul, B. (2014) 'Telling hard truths and decolonisation', in Kidd, J., Drago, A., Ryall A. and Stearn, M. (eds) Challenging History in the Museum. International Perspectives, 33-46, Farnham: Ashgate.

Peers, L. and Brown, A. K. (2003) 'Introduction,' in Peers, L. and Brown, A. K. (eds) Museums and Source Communities, 1-16, London and New York: Routledge.

Rentzhog, S. (2007) Friluftsmuseerna: en skandinavisk idé erövrar världen. Stokholm: Carlssons.

Sandell, R. ([2002] 2007a) 'Museums and combating social inequality', in Watson, S. (ed) Museums and their Communities, 95-113, London and New York: Routledge.

(2007b) Museums, Prejudice and the Reframing of Difference. London and New York: Routledge.

Sandell, R. and Nightingale, E. (2013) Museums, Equality and Social Justice. London and New York: Routledge.

Smith, J.K. 2014. The Museum Effect. How Museums, Libraries, and Cultural Institutions Educate and Civilize Society. Lanham, Maryland and Plymuth, UK: Rowman \& Littlefield Publishers.

Smith, L. (2015) 'Theorizing museum and heritage visiting' in Witcomb, A. and Message, K. (eds.) The International Handbooks of Museum Studies: Museum Theory. First edition. 459 - 484. New York: John Wiley \& Sons, Ltd.

Srinivasan, R., Becvar, K.M., Boast, R. and Enote, J. (2010) 'Diverse Knowledges and Contact Zones within the Digital Museum' Science, Technology and Human Values, (35) 735-768.

Spangen, M. (2015) Without a trace? The Sámi in the Swedish History Museum. Nordisk Museologi (2)17-32.

St. meld. nr. 62 (1991-1992) Ny landsplan for nasjonalparker og andre større verneområder i Norge (nasjonalparkmeldingen). Oslo: Miljøverndepartementet.

St.meld. nr. 22 (1999-2000) Kjelder til kunnskap og oppleving: Om arkiv, bibliotek og museum i ei IKT-tid og om bygningsmessige rammevilkår på kulturområdet. Oslo: Kulturdepartementet.

Swan, D. C and Jordan, M. P. (2015) 'Contingent Collaborations: Patterns of Reciprocity in Museum-Community Partnerships.' Journal of Folklore Research, 53 (1) 39 - 84.

Tunbridge, J. E. and Ashworth, G. J. (1996) Dissonant heritage: the management of the 
past as a resource in conflict, Chichester: Wiley.

Vergo, P. (1997) The New Museology. London: Reaktion Books.

Waterton, E. and Smith, L. (2010) 'The recognition and misrecognition of community heritage.' International Journal of Heritage Studies 16(1-2) 4-15

Watson, S. (2007) 'Introduction to Part Three'; in': Watson, S. (ed.) Museums and their Communities; 269-275, London and New York: Routledge.

Webb, S. (2006) 'Making museums, making people: the representation of the Sámi through material culture', Public Archaeology, 5, 167-183.

Ydse, T.F. (2007) Museum, arkiv og samfunn. Kunnskapsbehov og utfordringer, Norsk Kulturråd, Oslo: Fagboksforlaget.

Zachrisson, I. (2004) Fanns det samer i Härjedalen i äldre tid? Om rättsprocesser och arkeologi', in Samisk forhistorie. Rapport fra konferanse i Lakselv 5.-6.september 2002, ed. K. Krogh and K. Schanche, 56-61, volume 1. Varangerbotn: Vàrjjat Sàmi Musea Càllosat/Varanger Samiske Museers Skrifter,

\section{${ }^{*}$ Grete Swensen}

Ethnologist and senior researcher at Norwegian Institute for Cultural Heritage Research. At the moment much of her research is related to how cultural heritage and cultural environments can be incorporated in today's physical planning, including how to integrate cultural heritage as a vital component in a sustainable urban development. One of the projects she is involved in is focusing on how immigrants of first and second generation interpret cultural heritage. Recent publication is Heritage, Democracy and the Public. Nordic Approaches. Ashgate, Farnham, eds. TS Guttormsen \& Swensen, G. (2016)

Grete Swensen, Phd ethnology

Senior researcher

Norwegian Institute for Cultural Heritage Research (NIKU)

PO Box 736 Sentrum,

$\mathrm{N}-0105$ Oslo,

Norway

http://www.niku.no

Visiting address: Storgata 2, 0155 Oslo

Phone: +47 23355045 